\title{
In memoriam Dr. Juan Montes Villarreal (1951-2020)
}

\author{
Leonardo Mancillas-Adame* \\ Endocrinology Division, Medical School and University Hospital "Dr. José Eleuterio González" Universidad Autónoma de Nuevo León, Monterrey, \\ Nuevo Leon, Mexico
}

It is with great sadness that the University's medical community was informed of the loss of one of their most outstanding members. He contributed during much of his professional life to the training of many generations of physicians; both primary care and specialists as well as academic health care professionals. After completing his training at the National Institute of Nutrition "Salvador Zubirán" (INNSZ), he quickly became involved in the scientific growth of the Internal Medicine residency at the "Dr. Jose Eleuterio Gonzalez" University Hospital. With his exceptional clinical and teaching abilities, along with a critical and constructive view of the generation of knowledge under his guidance, multiple generations of students, both undergraduate and graduate, clinical, and academic, have called him a mentor. This is unquestionably deserved and representative of his generosity in sharing his knowledge and his ways. I did not have the honor of being his formal student during my med school or postgraduate courses; however, I was his close friend and companion in many conversations, all of them inspiring. He was as much as a teacher to me as the rest of my teachers.

He was bright, and not only regarding his medical abilities in clinical practice or his teaching virtues; it would only take a moment during any day conversation or at a dinner to learn about all aspects of life, from philosophy to mathematics, chemical neurotransmitters, and world politics. Furthermore, social trends, teaching trends, generational behavioral changes in young or older people, perhaps some author lost in literature marketing but valuable in his messages, postgraduate student behavior, academic evaluations, the mystics of a professor, and so on. A conversation with him was quite an adventure, you knew the starting point yet not the end, and on many occasions, you could learn an important life lesson in between. Material possessions were not a focus of his, regardless of the fact that he was a well-known endocrinologist with a robust medical practice, well appreciated by all his patients due to his sensitivity.

In everyday academic life, at postgraduate meetings, in addition to his Coca Cola, his light jacket and the complaint on the low temperature of the meeting room, he would comment after listening carefully. A short comment, always up-to-date, one which pinpointed the diagnostic or treatment path. Just as all wise people, he was a great listener, providing few words in his answers, but very appropriate and on point.

Watching him lose his temper in an undergraduate or postgraduate session was unheard-of. In the process of teaching and preparing physicians, his motto was to seek a correct clinical judgment, the proper use of diagnostic examinations and to not abuse or overestimate the effects of treatment.

Publishing research was not his main interest; he always told me he did not feel comfortable writing in

\section{Correspondence:}

*Leonardo Mancillas-Adame

E-mail: leomancillas@gmail.com
Date of reception: 13-05-2020

Date of acceptance: 14-05-2020 DOI: 10.24875/RMU.M20000046
Available online: $18-06-2020$

Medicina Universitaria. 2020;22(3):140-141 www.medicinauniversitaria.org

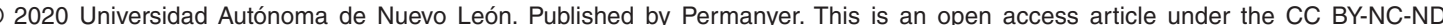
license (http://creativecommons.org/licenses/by-nc-nd/4.0/). 
English, and that German and Spanish were his strong suit. However, his mastery of the scientific method and his understanding of the objectives, or the "what do you want to know," was impeccable, not to mention his insight into what he read, always identifying with ease the strengths and weaknesses of any publication. His last article was one we wrote together. We had worked for hours on it, and I know it helped make this difficult time more bearable. For such a brilliant physician, understanding what occurred during his last year was too simple, being a part of his medical team is one of the tasks as a health professional that I will never forget nor I will ever find a way to thank him for the trust he placed in us to care for him. This year allowed him to watch his grandson become 1 year old, it let him plan, and it allowed him to say goodbye to many of us beforehand, knowing his time on earth was about to end.
Juan will be missed as a father, grandfather, fatherin-law, husband, teacher, colleague, and physician, a unique and unforgettable human being.

$$
\text { Rest in peace }
$$

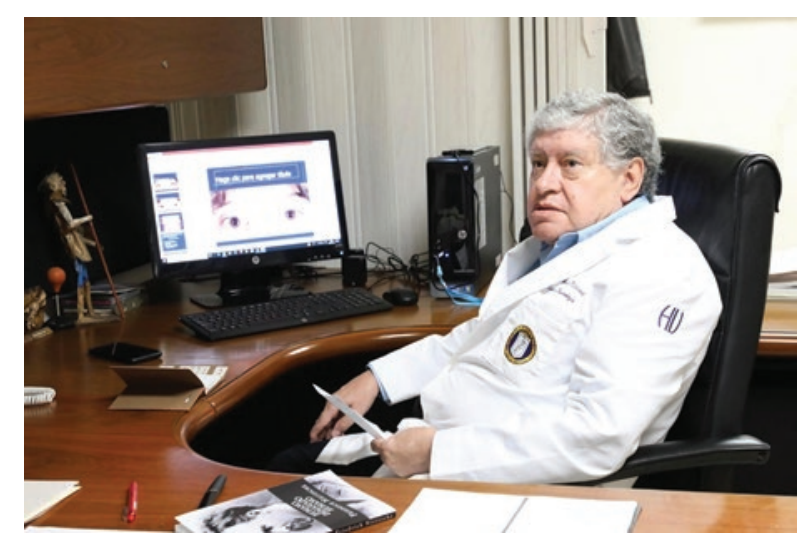

